\title{
DOPUSZCZALNOŚĆ KARY ŚMIERCI W UJĘCIU TADEUSZA ŚLIPKI. Kara śmierci rekapitulacją uprawnionej obrony
}

W jakim sensie akt zniszczenia życia ludzkiego, znany powszechnie pod nazwą kary śmierci, zarazem je afirmuje? Rezultatem podjęcia przez Tadeusza Ślipkę postawionego w tym pytaniu problemu jest jego stanowisko $\mathrm{w}$ sprawie podstaw ograniczonej dopuszczalności sankcji kapitalnej, które określa on umiarkowanym retencjonizmem lub - rzadziej - represjonizmem. We współczesnym sporze o karę śmierci stanowisko Ślipki prezentuje się jako oryginalna próba przezwyciężenia nieprzezwyciężalnej - zdaniem jej przeciwników sprzeczności istniejącej między stosowaniem tej kary i życiem osoby ludzkiej. Niewątpliwie dające się dostrzec pewne napięcie między karą śmierci i życiem - fundamentalnym dobrem osoby, będącym według niektórych głównym powodem jej kwestionowania ${ }^{1}$, dla Ślipki nie stanowi przesłanki, z której wynika słuszność bronionego przez nich stanowiska. W jego przekonaniu istnieją także poważne racje, które - rozważone bez emocji i uprzedzeń - pozwalają nie tylko złagodzić to napięcie, ale również uzasadnić słuszność umiarkowanego retencjonizmu, stanowiska zrównoważonego w tym sporze.

\section{Droga uzasadnienia kary śmierci}

Uzasadnienie kary śmierci jako sankcji wymierzanej za najpoważniejsze wykroczenia przeciwko porządkowi moralnemu przez wyprowadzenie tego uzasadnienia z prawa moralnego (sedno referowanego tu stanowiska) podyktowane jest specyfiką samej kary śmierci. Wyjątkowość tej kary, płynąca stąd, że stanowi ona szczególnie dotkliwą formę penalizacji, determinuje poniekąd charakter jej uzasadnienia. Mając tego świadomość, Ślipko kieruje się tożsamością przestępstwa i kary. Skupia się on głównie na dopuszczalności kary śmierci w sensie sprawie-

1 Por. np. racje wysuwane przeciwko sankcji kapitalnej z pozycji etyki afirmacji godności osoby ludzkiej opublikowane w kwartalniku „Ethos” 2 (1989) 5, s. 137 n. 
dliwej retrybucji za morderstwo. W ten sposób wyklucza nie tylko możliwość wymierzania tej sankcji za inne niż ono przestępstwa, ale także pośrednio podejmuje dyskusję zwłaszcza z radykalnym abolicjonizmem. Kwestionuje on bowiem dopuszczalność kary śmierci nawet tylko w tym jednym przypadku naruszenia prawa moralnego ${ }^{2}$.

Istota przyjętego przez Ślipkę kryterium tożsamości przestępstwa i kary, czyli morderstwa i kary śmierci, będącego punktem wyjścia jego retencjonizmu, daje się jeszcze lepiej uchwycić, jeśli uwypukli się zachodzące między nimi podobieństwo. Do natury morderstwa należy uśmiercenie (na ogół niewinnego) człowieka. Ale i karze śmierci trudno odmówić analogicznego charakteru. Podobieństwo to dotyczy także nieodwracalności śmierci jako bezpośredniego i niemożliwego do naprawienia skutku obu działań. Co więcej, nie osłabia go nawet zasadnicza odmienność motywacji przyświecająca zabójcy i sędziemu, decydującemu z mandatu i w imieniu społeczeństwa o wydaniu nań wyroku śmierci. To właśnie nieodwracalność śmierci, tego czynnika, z uwagi na który kara śmierci słusznie jest traktowana jako wyjątkowa wśród sankcji o charakterze kryminalnym, wyznacza umiarkowanemu retencjonizmowi jego główne zadanie, polegające na ustaleniu moralnego statusu tej kary ${ }^{3}$.

Warto odnotować, że dzieje kary śmierci są znacznie starsze niż spór o nią. Spór zainicjowano dopiero w XVIII w. Do tego czasu karę tę uzasadniano głównie tym, że stanowi ona skuteczny, a tym samym niezastąpiony środek służący zachowaniu ustanowionego przez Boga porządku społecznego, na którego czele postawił On władcę. Władca jako osoba reprezentująca Boga odgrywała wobec poddanych rolę stróża i gwaranta tego porządku ${ }^{4}$ Kary były więc surowe. Karę śmierci stosowano powszechnie i nierzadko w sposób wyjątkowo wyrafinowany ${ }^{5}$. W ich wykonywaniu chodziło głównie o skuteczne odstraszenie od łamania prawa, stanowiącego kluczowy instrument nienaruszalności całego ustroju społecznego. Najbardziej jednak wpływowe uzasadnienie kary śmierci, jakie pojawiło się w kręgu kultury chrześcijańskiej, było dziełem św. Tomasza z Akwinu. W jego ustosunkowaniu się do kary śmierci dają się odkryć znamiona wspomnianego podejścia do kwestii jej usprawiedliwiania; podejście to miało za sobą zresztą znacznie dłuższą tradycję. Było ono naznaczone teologiczną wizją porządku społecznego impliku-

2 Por. T. Ślıpкo, Granice życia. Dylematy współczesnej bioetyki, Kraków 1994, s. 317-318; tenże, Kara śmierci z teologicznego i filozoficznego punktu widzenia, Kraków 2000, s. 130-133.

3 Por. T. ŚLIPKo, Etyczne spojrzenie na najwyższy wymiar kary, [W:] J. BRUsıŁo (red.), Evangelium vitae. Dobra nowina o życiu ludzkim. Materiały na temat encykliki Jana Pawła II Evangelium vitae oraz dyskusja panelowa o karze śmierci, Kraków 1995, s. 126.

4 Por. S. Salmonowicz, Prawo karne oświeconego Absolutyzmu, „Roczniki Towarzystwa Naukowego w Toruniu” 71 (1966) 2, s. 31; B. STrub, Der Einfluss der Aufklärung auf die Todesstrafe, Zürich 1973, s. 8.

5 Por. W. Middendorff, Todesstrafe - Ja oder Nein?, Freiburg 1962, s. 33. 
jącą możliwość zabicia pojedynczego człowieka w przypadku, gdyby zagrażał on dobru publicznemu. Takiego człowieka już nie należało - w mniemaniu Tomasza - traktować jak kogoś, komu jeszcze przysługuje godność, lecz jak kogoś, kto upodabniając się do bestii, sam sobie tę godność odebrał'

Co prawda nie można poddawać w wątpliwość tego, że św. Tomasz zdawał sobie sprawę ze szczególnej doskonałości bytu osobowego. Świadczą o tym zresztą dobitnie jego własne słowa: Dicendum, quod persona significat id, quod est perfectissimum in tota natura, scilicet subsistens in rationali natura ${ }^{7}$. Jednakże nie uważa on, by owa doskonałość osoby mogła sama w sobie być powodem, dla którego należałoby odstąpić od kary śmierci. W tym miejscu dotykamy dość istotnej kwestii. Można ją wyrazić w następującym pytaniu: jaka jest przyczyna negatywnej oceny Tomaszowego retencjonizmu, z którą spotykamy się u Ślipki? Czymś bowiem znamiennym wydaje się to, iż autor, którego myśl filozoficzna jest głęboko zakorzeniona w tradycji tomistycznej, poszukując własnego rozwiązania problemu kary śmierci, nie tylko nie nawiązuje do Tomasza w tym względzie, lecz poddaje go krytyce. Przyczyny tej należy chyba upatrywać w strukturze retencjonizmu średniowiecznego myśliciela. Ma on charakter eudajmonistyczno-teleologiczny. W konsekwencji nie wyklucza się w nim możliwości zdeprecjonowania ludzkiej godności złoczyńcy, a przez to również jego życia. Zaznaczmy jednak, że - nawiązując w kontekście kary śmierci do godności - Tomasz ma na myśli godność w znaczeniu etycznym. A więc chodzi mu o taką godność, której nie przysługuje nienaruszalność, ponieważ jest ona uzależniona od moralnie dodatniej wartości spełnianych przez danego człowieka czynów ${ }^{8}$. Tymczasem w retencjonizmie Ślipki główny akcent zostaje położony w tym miejscu, w którym Doktor Anielski wykazuje pewną chwiejność, a którym jest niezależna od postępowania danego człowieka obiektywna wartość bytu ludzkiego i wiążące się z nią prawo do życia' ${ }^{9}$. Innymi słowy, Tomaszowe uzasadnienie kary śmierci nie spełnia stawianego takiemu uzasadnieniu przez Ślipkę wymogu oparcia go na moralności. Rzetelnie bowiem wypracowywany retencjonizm nie może bagatelizować tak ważnego problemu jak godność, nawet gdyby w danym przypadku jej nosicielem był zbrodniarz. Nie wolno mu tym bardziej ignorować wyjątkowego charakteru kary śmierci, lecz musi uwzględniać oba te elementy i w jakiś sposób je ze sobą pogodzić. Wszak moralność czynu, a w analizowanej sytuacji jest nim kara śmierci, oprócz jego sprawcy zakłada istnienie tego, do którego się on odnosi, czyli istnienie drugiej osoby.

\footnotetext{
Por. S. Th. II-II, q. 64, a. 2, ad. 2-3.

S. Th. I, q. 29, a. 3 resp.

8 Por. H. Majkrzak, Wolność fundamentem godności człowieka w ujęciu św. Tomasza z Akwinu, [W:] Z. J. Zdybicka (red.), Wolność we wspótczesnej kulturze. Materiały V Światowego Kongresu Filozofii Chrześcijańskiej KUL - Lublin 20-25 sierpnia 1996, Lublin 1997, s. 387.

$9 \quad$ Por. T. Ślıipko, Kara śmierci z teologicznego..., dz. cyt., s. 124.
} 
Tego samego wymogu nie spełniają również inne - teoretycznie możliwe i stosowane - uzasadnienia kary śmierci. Interesująca Ślipkę jej strona etyczna nie może być ustalana na podstawie przyjętych przesłanek prawnych czy politycznych lub ze względu na użyteczność publiczną. Nieprzydatność tych przesłanek w budowaniu etycznej struktury kary śmierci tłumaczy on tym, że moralne dobro i zło, jako urzeczywistniające się w czynach jednostek ludzkich, nie sprowadza się do zgodności lub niezgodności z prawem, normatywnie podlegającym moralności, z interesem danej grupy społecznej, a nawet interesem całego społeczeństwa. Akceptacja którejkolwiek z nich jako podstawy moralnej godziwości kary śmierci, torującej tym samym drogę do jej praktycznego stosowania, byłaby nieporozumieniem, ponieważ podporządkowywałaby osobę innym dobrom (celom) niż ona ${ }^{10}$. Siła racji, które mają przemawiać za - choćby tylko ograniczoną - dopuszczalnością tak radykalnej sankcji karnej, musi być taka, by racje te były w stanie zrównoważyć skutek tej kary, tj. fakt bezpowrotnego zniszczenia życia ludzkiego.

\section{Aksjologia życia ludzkiego}

Zabierając głos w dyskusji na temat kary śmierci z pozycji rzecznika jej ograniczonej dopuszczalności, Ślipko odwołuje się więc do uzasadnienia aksjologicznego. Czyni to, ponieważ jedynie w nim Ślipko upatruje szansy na podanie racji, które będą równoważyć odebranie życia człowiekowi. Jego istotą jest ustalenie moralnego statusu kary śmierci, który stanowiłby dla niej podstawę regulacji prawnych. Z jednej strony rozważa on w tym celu treść ogólnie pojętego prawa do życia, $z$ drugiej zaś dokonuje gruntowniejszej eksploracji konsekwencji, jakie pociąga za sobą jego naruszenie. W kwestii interpretacji zakresu obowiązywalności prawa do życia Ślipko dostrzega pewną stronniczą skłonność. Skłonność ta polega na tym, że w świetle konfliktu agresor - ofiara, stanowiącego podstawowy kontekst jego uzasadnienia umiarkowanego retencjonizmu, bierze się zazwyczaj pod uwagę tylko nienaruszalność życia agresora, a pomija nienaruszalność życia ofiary agresora ${ }^{11}$.

Chociaż Ślipko postrzega tę skłonność jako charakterystyczną cechę współczesnego abolicjonizmu, nie poświęca jej jednak większej uwagi. Istotniejszą dlań sprawą jest znalezienie odpowiedzi na pytanie, czy i jak prawo do życia może implikować karę śmierci. Odpowiedzi na powyższe pytanie szuka on w aksjologii życia ludzkiego, wynikającej z tkwienia bytowej struktury tego życia w bytowej strukturze osoby ludzkiej. „Kiedy [...] mówimy o »życiu« czy »egzystencji« człowieka, nie pojmujemy tego życia jako jakiejś części jego realnego bytu, swoiste-

10 Por. T. Ślipko, Granice życia..., dz. cyt., s. 315-317.

11 Por. tenże, Etyczne spojrzenie..., dz. cyt., s. 103. 
go dobra, które da się wyodrębnić z całokształtu człowieczeństwa i porównać $\mathrm{z}$ innymi dobrami [...]. Realistyczne spojrzenie na życie każe je pojmować integralnie jako istnienie tożsame z całą realną podmiotowością człowieka, czyli jego indywidualnym konkretnym istnieniem. [...] Życie człowieka nie jest czymś w człowieku, ale samym żyjącym człowiekiem i przedstawia taką bytową strukturę, jaką reprezentuje ów człowiek. [...] Życie ludzkie jest obiektywnie tożsame $\mathrm{z}$ osobową strukturą bytu ludzkiego, tej zaś strukturze przysługuje [...] fundamentalna godność i wartość moralna"12. Tej godności - a jest to godność uniwersalna, obejmuje bowiem każdą istotę ludzką - żadna z nich od nikogo nie uzyskuje i nikomu jej nie zawdzięcza. Pojedynczy człowiek nabywa ją przez to, kim jest, czyli na mocy samego człowieczeństwa. Ono jest koniecznym i wystarczającym warunkiem do tego, by tę godność dostrzec i uznać w każdym człowieku. W oparciu o nią Ślipko głosi ponadto zasadę aksjologicznej równości wszystkich ludzi, pod którą rozumie równość wszystkich osób ludzkich w tak pojętej godności. Opisane tu w wielkim skrócie bogactwo człowieczeństwa, cenność natury ludzkiej, określane terminem "godność», jest więc czynnikiem sprawczym tego, że życie osoby ludzkiej ma swój doniosły sens czy wymiar aksjologiczny, przesądzający o nienaruszalności jej życia ${ }^{13}$.

Jednocześnie ta bezprecedensowa ranga i pozycja ludzkiego życia biologicznego, tzn. słowem jego wyjątkowość mająca podstawę w doskonałości ontycznej osobowego bytu ludzkiego, którym jest człowiek, decyduje też o tym, że spośród innych istot tylko jemu przysługuje prawo do życia. Jedynie jego życie cieszy się nietykalnością i podlega ochronie. Nie chroni się je zaś z tego powodu, że człowiek jest istotą żywą. Takimi istotami są także zwierzęta, a trudno przecież traktować ich życie jako nienaruszalne, a przynajmniej nie w takim zakresie jak życie człowieka. Życie ludzkie jest nienaruszalne dlatego, że człowiek jest osobą ${ }^{14}$. Możliwość osobowego samospełnienia się człowieka, możliwość jego integralnego doskonalenia się z racji bycia osobą ludzką, jest wobec tego w niemałej mierze uzależniona od zachowania życia biologicznego. Przeciwko temu dobru może wystąpić inny człowiek. Występuje on zaś przeciwko niemu wówczas, gdy wciela się w rolę agresora, czyli podejmuje zamach na fundamentalne dobro osoby ${ }^{15}$.

12 Tenże, Granice życia..., dz. cyt., s. 243.

13 Por. T. Ślipko, Granice życia..., dz. cyt., s. 243-244 i 286.

14 Por. J. Ratzinger, Życie - fundamentalna wartościa i nienaruszalnym prawem człowieka, „Ethos” 2 (1989) 5, s. 21.

15 Por. T. Ślipko, Kara śmierci z teologicznego..., dz. cyt., s. 125-126; tenże, Kara śmierci z filozoficznego punktu widzenia, „Resovia Sacra” 13 (2006), s. 132. 


\section{Agresja a kara śmierci}

Agresorem człowiek się staje ${ }^{16}$. A staje się nim przez nadanie swym działaniom określonego charakteru, polegającego na dążeniu wprost do uśmiercenia innego człowieka, który go do tego nie sprowokował. Nie każda jednak agresja ściąga automatycznie na jej sprawcę karę śmierci, lecz jedynie agresja spełniająca określone warunki. Ślipko ma na myśli agresję aktualną, a nadto podkreśla, że podejmująca ją osoba musi być poczytalna. Nie mogą się po prostu pojawić w konkretnym przypadku okoliczności łagodzące, które byłyby podstawą do wymierzenia winowajcy łagodniejszej sankcji karnej. W agresji ma miejsce konflikt aksjologiczny: ocalenie życia jej ofiary wydaje się niekiedy niezłomnie prowadzić do unicestwienia życia agresora. Kiedy agresja okaże się skuteczna, wówczas w grę wchodzi morderstwo. Aby więc kogoś, kto dopuścił się agresji, można było zakwalifikować jako podpadającego pod zagrożenie karą śmierci, konieczne jest współwystąpienie tego trzeciego warunku, tj. śmiertelnego skutku agresji ${ }^{17}$.

Agresja w powyższym rozumieniu implikuje ograniczenie nietykalności życia agresora i uprawnioną obronę życia człowieka, przeciwko któremu on wystąpił. Należy zauważyć, że w kontekście zawiązującej się w agresji relacji między osobami (agresja a samoobrona) Ślipko nieco inaczej jednak interpretuje, mającą tutaj poniekąd klasyczne zastosowanie, zasadę „podwójnego skutku”. W myśl tradycyjnego pojmowania tej zasady, jej dopuszczalność określa intencja osoby narażonej na utratę życia. Ślipko proponuje korektę tego punktu widzenia. Jeśli bowiem obiektywnie oceni się charakter relacji, jaka zawiązuje się w agresji między dwoma podmiotami, to trzeba stwierdzić, że z jednej strony sposób obrony życia determinuje struktura działań napastnika. Owa struktura polega na dążeniu wprost do obranego celu, a jest nim spowodowanie śmierci. Natomiast $\mathrm{z}$ drugiej strony determinuje go aktualna niemożliwość posłużenia się przez obrońcę takimi środkami, które nie uśmiercą agresora, a zarazem pomogą obrońcy ocalić własne życie. I tylko z tego względu $\mathrm{z}$ uprawnionej obrony, zgodnie $\mathrm{z}$ tradycyjną wykładnią tej zasady, płyną dwa skutki: śmierć agresora i ocalenie życia. Ale Ślipko nie zgadza się z nią w tym punkcie, w którym jest mowa o sposobie wynikania owych skutków. Wyjaśnia on, że jeśli spojrzy się na samoobronę z per-

16 Wyłącznie świadomy i wolny podmiot, człowiek, jest w stanie zabić, a nadto znaleźć dla własnego postępowania inny motyw, aniżeli biologiczny instynkt samozachowawczy. Naruszając normę moralną, decydując się na działanie wbrew niej, człowiek staje się sprawcą moralnego zła, nastąpiło więc u niego skrzywienie aktu woli: „U człowieka zabójstwo nie jest nieodpartym gestem przetrwania. Jest wolą śmierci, przyjętą świadomie, za zgodą, która stała się mną samym; dopiero później, i jako konsekwencja, umiera ktoś inny”. A. Rızzı, Sens egzystencji ludzkiej w perspektywie decyzji moralnej, [W:] Perspektywy i problemy teologii moralnej, tłum. T. Mieszkowski, Warszawa 1982, s. 86.

17 Por. T. Ślıpкo, Za czy przeciw życiu? Pokłosie dyskusji, Kraków-Warszawa 1992, s. 39-40; tenże, Granice życia..., dz. cyt., s. 302; 311; 329-330. 
spektywy dobra zaatakowanego człowieka, to okaże się, że najważniejsza jest jej efektywność. Nie sposób przecież sensownie podważać tego, że znajdującemu się $\mathrm{w}$ tak dramatycznym położeniu człowiekowi zależy nade wszystko na ocaleniu życia. Jednakże aby zaatakowany mógł skutecznie działać we własnej obronie, musi swoje działanie upodobnić do struktury agresji. Nie może on nie chcieć - mówiąc inaczej - wprost dążyć do zabicia agresora, jeśli chce ocalić własne życie. Zatem ewentualne zabójstwo w samoobronie nie może być - zdaniem Ślipki - jedynie dopuszczone lub tolerowane. Na tej podstawie Ślipko twierdzi, że obrońca kieruje się faktycznie dwiema intencjami: zabiciem agresora i ocaleniem swojego życia ${ }^{18}$.

Poza sytuacją agresji aktualnej, lecz tylko takiej, w której nie ma możliwości uchylenia się od zadania śmiertelnego ciosu ratującego życie, zabójstwo we własnej obronie jest niedopuszczalne. Agresja jako akt, którego istota polega na dążeniu wprost do pozbawienia kogoś życia, a która właśnie z tego powodu musi być potępiona jako absolutnie zła moralnie, sama w sobie nie ma wszakże mocy sprawczej zdolnej odebrać godność człowiekowi, który ponosi za nią odpowiedzialność. Agresja nie unieważnia aksjologicznej równości wszystkich osób ludzkich w odniesieniu do osoby jej sprawcy. A wobec tego agresor nawet w chwili dokonywania zbrodniczego czynu zachowuje prawo do życia. Nie zmienia tego fakt, że on sam wystąpił przeciwko temu prawu w stosunku do drugiego człowieka. Mimo to jest całkowicie jasne, że jednak w sytuacji agresji nienaruszalność życia agresora nie jest i nie może być bezwzględna, lecz musi być w jakimś stopniu ograniczona $\mathrm{z}$ uwagi na nienaruszalność życia i możliwość jego skutecznej obrony przez poszkodowaną w niej osobę. „To ograniczenie jest właśnie owym urządzeniem [tzn. uprawnioną obroną - K. B.] postulowanym przez zasadę aksjologicznej równości wszystkich ludzi celem stworzenia dla obrońcy zaatakowanej wartości [tj. jego życia - K. B.] równej szansy w walce z agresorem"19. Rozważenie agresji pod kątem godności i prawa do życia agresora każe z kolei stwierdzić, że nakłada to na broniącą się przed nim osobę pewne ograniczenia. Konieczność podjęcia walki z agresorem we własnej obronie nie oznacza dowolności w doborze środków, którymi wolno się jej w tym celu posługiwać. Ślipko wyraźnie obliguje obrońcę do tego, by skuteczność tych środków nie prowadziła do odebrania napastnikowi życia, o ile oczywiście jest to możliwe w danym przypadku. Śmiertelny cios zadany agresorowi musi być więc traktowany jako ultima ratio - jedyny i ostateczny sposób obrony życia, od którego nie można się było w żaden sposób uchylić. I tak zresztą traktuje go Ślipko ${ }^{20}$. Stąd posłużenie się nim w sytuacji, w której obrońca dysponowałby jeszcze innymi środkami obrony

18 Por. tenże, Granice życia..., dz. cyt., s. 297-298; tenże, Kara śmierci z filozoficznego..., art. cyt., s. $128-129$.

19 T. ŚLıpкo, Granice życie..., dz. cyt., s. 305.

20 Por. tenże, Etyczne aspekty kary śmierci, [W:] J. KRUKowski, F. Lempa (red.), Kościót i prawo, T. VII, Lublin 1990, s. 45. 
własnej, oznaczałoby, że nie był on w okolicznościach usprawiedliwiających takie działanie i nadużył prawa do obrony koniecznej ${ }^{21}$.

Wszystko, co zostało dotychczas powiedziane, zwłaszcza w ostatnich słowach, przybliża nas do kluczowego ogniwa umiarkowanego retencjonizmu Ślipki. Naszkicowany w nich układ zdarzeń między agresorem i ofiarą ma poniekąd teoretyczny charakter. Nietrudno stąd wyciągnąć wniosek, że nie za każdym razem musi się on odwzorować w sytuacji realnych działań podejmowanych przez oba podmioty biorące udział w konflikcie. To, co daje się odczytać $\mathrm{z}$ teorii obrony koniecznej, sprowadza się do zaproponowania człowiekowi określonych reguł kierujących moralną stroną jego zachowania na wypadek konfliktu $\mathrm{z}$ agresorem. Jak powiedzieliśmy, mają one teoretyczny charakter, ale mimo to nie są pozbawione praktycznych konkluzji; do tego ma z założenia prowadzić teoria etyczna. Nikt jednak w oparciu o tę teorię nie ośmieli się przewidywać, jaka będzie skuteczność aktów samoobronnych, ani tym bardziej nikt nie jest w stanie zagwarantować takiej skuteczności. Ślipko ma tego świadomość i dlatego uwypukla właśnie ten wątek obrony koniecznej. Nie był on co prawda podejmowany w ramach różnych odmian retencjonizmu, ale w przekonaniu Ślipki na to zasługuje. Wykorzystując więc w swej koncepcji kary śmierci to, że obrona własnego życia w walce $\mathrm{z}$ agresorem okazuje się niekiedy nieskuteczna, Ślipko przenosi możliwość tej obrony na karę śmierci, która w pewnym sensie stanowiłaby jej skuteczną kontynuację. Prawo do życia rozpatrywane w ogólności stanowi, jak wiadomo, moralną podstawę do obrony życia w obliczu skierowanej przeciwko niemu agresji, a nawet legitymizuje zabójstwo we własnej obronie. Ale przecież nie nadaje ono realnym aktom, jakie podmiot podejmuje $\mathrm{w}$ tym celu, właściwości gwarantującej im skuteczność. Wymownym dowodem na to jest morderstwo. Czy nie świadczy ono o niepomyślnym, czyli nieskutecznym, dla ofiary agresji obrocie sprawy, na co mogły wpłynąć całkowicie przypadkowe i niezależne od jej woli czynniki? Czy morderstwo nie świadczy także o tym, że być może ofiara w ogóle nie miała żadnej szansy, by tę obronę podjąć? Wreszcie pytanie najważniejsze: czy w świetle tego wszystkiego można wyobrazić sobie bardziej niesprawiedliwą sytuację, jak odebranie niewinnej osobie życia, które do chwili jego utraty było dlań dobrem fundamentalnym?22 $\mathrm{W}$ odpowiedzi na te pytania trzeba stwierdzić, że akt bezpowrotnego zniszczenia życia ofiary agresji, tragiczny finał świadomie działającego w tym celu innego człowieka, to powód, dla którego Ślipko staje w obronie jej życia, a nie życia sprawcy agresji. Z tego samego powodu domaga się on, by to jedno z najpoważniejszych naruszeń prawa moralnego odcisnęło się na nim w postaci podobnego aktu wymierzonego w jego życie. „Akt agresji oznacza sferę działania, w której życie agresora zachowuje

21 Por. tenże, Kara śmierci z teologicznego..., dz. cyt., s. 127; 137.

22 Por. T. Ślipko, Kara śmierci z teologicznego..., dz. cyt., s. 134-135. 
tylko bytowość fizyczną pozbawioną wartościowości moralnej”23. W przeświadczeniu Ślipki prawo do obrony życia ofiary niesprawiedliwego działania agresora może i powinno być kontynuowane. Wydaje się zaś to możliwe dzięki przeniesieniu tego prawa na wymiar sprawiedliwości, który posługuje się karą śmierci. „Ze śmiercią ofiary agresji nie schodzi do grobu jej moralne prawo do życia i do jego obrony. Wraz z nim nie ustaje wołanie tego prawa o wymierzenie sprawiedliwej sankcji. [...] Ponieważ nie dane było ofierze napaści skorzystać z tego prawa, wobec tego prawo to zezwala państwu jako gwarantowi porządku sprawiedliwości uczynić to w ramach sankcji wymaganej przez sprawiedliwość. Warunkom tym czyni zadość również kara śmierci i na tej podstawie nie można jej odmówić zasadniczej moralnej dopuszczalności” ${ }^{24}$. W ten sposób Ślipko udziela odpowiedzi na podstawowe interesujące go pytanie, tj. pytanie o moralny status kary śmierci. Niniejsza odpowiedź, do której wiódł nas autor swoim wywodem, może być także traktowana jako forma jego krytycznego ustosunkowania się do radykalnego abolicjonizmu. Nie należy wobec tego - zdaniem Ślipki - doszukiwać się w karze śmierci sankcji moralnie złej; nie podważa jej zasadniczo nawet etyka chrześcijańska ${ }^{25}$. Przeciwnie: jest ona sprawiedliwą retrybucją, nieprzekraczającą granic uprawnionej obrony. Między morderstwem a karą śmierci zachodzi proporcja, albowiem za świadome targnięcie się na cudze życie można zapłacić tylko życiem własnym $^{26}$. Kara śmierci jest zarazem moralnie słuszna, ponieważ przez usunięcie zbrodniarza ze społeczeństwa afirmuje absolutną nienaruszalność życia każdego niewinnego człowieka ${ }^{27}$. Niemożliwość resocjalizacji przestępcy uzasadnia charakter zbrodni, jakiej się dopuścił ${ }^{28}$.

\section{Próba oceny}

Problematyką kary śmierci zajmowano się u nas po wojnie wielokrotnie, czyniąc to na ogół przy okazji wysuwanych projektów nowelizacji kodeksu karnego. W pewnym sensie był to również okres zmagania się o zniesienie kary śmierci, choć nigdy nie brakowało i nie brakuje także jej żarliwych obrońców.

23 Tenże, Granice życia.., dz. cyt., s. 330.

24 Tenże, Kara śmierci z teologicznego..., dz. cyt., s. 135-136; por. tenże, Granice życia..., dz. cyt., s. 330-331.

25 Por. T. ŚLIPKo, Granice życia..., dz. cyt., s. 334.

26 Por. tamże, s. 331.

27 Podobną argumentacją posługuje się S. Michalkiewicz: „Wykonywanie ochronnej funkcji prawa powinno zmierzać do utrzymania sytuacji co najmniej takiej, jaka istniała na etapie usiłowania, tzn. dopóki ofiara mogła skorzystać z obrony koniecznej. Zadaniem prawa karnego powinno być przedłużenie zagrożenia życia napastnika również na okres, gdy ofiara została doprowadzona do stanu bezbronności lub pozbawiona życia”. Cyt. za P. Bartula, Kara śmierci - powracający dylemat, Kraków 1998, s. 117.

28 Por. T. Ślıpko, Granice życia..., dz. cyt., s. 324. 
Do tego zagadnienia Ślipko powrócił w czasie, w którym karę śmierci zastępuje się karą dożywotniego więzienia. Z punktu widzenia obrońców można by więc mówić o pewnym niepowodzeniu, podczas gdy z punktu widzenia przeciwników kary śmierci o pomyślnym zakończeniu batalii o jej zniesienie. Niezależnie jednak od indywidualnej oceny aktualnego i przewidywanego stanu prawnego w Polsce w tej kwestii powód, dla którego Ślipko ponownie się nią zajął, zasługuje niewątpliwie na uwagę. Jednakże nie jest nim to, że przedstawiony przez nas pogląd Ślipki na karę śmierci należy wraz z nim traktować po części jako jego nieukrywaną reakcję na współczesną falę abolicjonistycznej mody, a częściowo także na radykalny abolicjonizm poszukujący inspiracji i wsparcia w etyce chrześcijańskiej. Znacznie ważniejszy od tego wydaje się nieszablonowy sposób, w jaki Ślipko, odpowiadając na tę tendencję, uzasadnia karę śmierci. Właśnie ten aspekt wydaje się chyba najbardziej dojrzałą cechą jego retencjonizmu. W jakimś stopniu do poszukiwania odmiennego od dotychczasowych uzasadnień kary śmierci zmusza sama specyfika tej kary. Trudno byłoby bowiem zaprzeczyć, że nie stanowi ona sankcji mającej na celu definitywne wyeliminowanie człowieka ze społeczeństwa. Ale właśnie w tym tkwi sedno penalizacji, którą ta kara realizuje, a równocześnie główny powód sprzeciwu wobec niej. Toteż obowiązek związania $\mathrm{z}$ działaniem nastawionym na unicestwianie proporcjonalnych $\mathrm{w}$ stosunku doń racji spada zawsze na tego, kto to działanie aprobuje. Wszak istnienie jako wartość bardziej niż występowanie przeciwko niemu zakłada jego afirmację $e^{29}$. W przypadku zaś koncepcji kary śmierci Ślipki mamy do czynienia z niecodzienną sytuacją: afirmacja życia jednego człowieka dokonuje się kosztem odebrania życia innemu człowiekowi. Jeśli zatem w perspektywie tego dobra, którym jest człowiek jako osoba ludzka, jak i jego istnienia, kara śmierci nie ma być odbierana jako odruch bezdusznej zemsty, to trzeba podać odpowiednie racje równoważące tak radykalną i nieodwracalną w swych skutkach ingerencję w to dobro. Ślipko jest świadomy wagi tego problemu.

Dla Ślipki jedynie właściwą drogą rozstrzygnięcia tego problemu jest aksjologia życia ludzkiego. Paradoksalnie nie brak takich, którzy właśnie w niej upatrują głównego wroga kary śmierci, a jednocześnie osobisty powód niechęci wobec niej. Dlatego zarówno w miejsce społeczno-religijnego uzasadnienia kary śmierci w ujęciu św. Tomasza, jak i innych typów jej uzasadniania Ślipko wprowadza uzasadnienie o charakterze antropologiczno-etycznym. W tym sensie ujmuje on problem kary śmierci w jego podstawowym - personalistycznym wymiarze. Ale i dostrzeganie w jego retencjonizmie rysu deontologicznego nie wydaje się pozbawione podstaw. W ujęciu krakowskiego etyka kara śmierci jawi się jako akt sprawiedliwego postępowania ze zbrodniarzem w świetle tej niesprawiedliwości, którą wyrządził on niewinnemu człowiekowi, odbierając mu życie („życie za ży-

29 Por. W. Stróżowski, Etyka afirmacji, „Znak” 13 (1961) 89, s. 1461-1481. 
cie”). Wysokość sankcji odpowiada tu ciężkości przestępstwa. Kary śmierci nie wymierza się „po coś”, lecz „za coś”. To chyba definitywnie wyjaśnia, dlaczego Ślipko tak niewiele miejsca poświęca resocjalizacji, ograniczając się jedynie do konstatacji, że kara śmierci, będąc sprawiedliwą retrybucją za morderstwo, nie obejmuje tego wymiaru kary, który bywa uwzględniany w odniesieniu do sprawców przestępstw lżejszych, aniżeli morderstwo.

Przechodząc do próby oceny umiarkowanego retencjonizmu Ślipki, przyjrzyjmy się jeszcze raz podstawom jego niezaprzeczalnej osobliwości. Stanowią o niej trzy ściśle ze sobą zespolone elementy, do których odnosi się owa ocena. Pierwszy spośród nich wiąże się z tezą, że zaatakowanemu człowiekowi przyświeca podwójna intencja. Aby mógł on ocalić własne życie, musi wprost spowodować śmierć napastnika. Gdyby się to nie powiodło i w rezultacie to agresor wyszedłby zwycięsko z konfliktu, wówczas jego śmierć wolno spowodować za pośrednictwem kary śmierci. Drugą charakterystyczną cechą dopuszczalności kary śmierci w ujęciu Ślipki jest więc analogia między obroną konieczną i karą śmierci, tj. połączenie nieskutecznej samoobrony z karą śmierci jako jej skuteczną kontynuacją. „Argumentacja Ślipki - w odczuciu B. Chyrowicz - sprawia wrażenie, jakby autor nie rozpatrywał zabójstwa w samoobronie, ale zabójstwa dla samoobrony"30. Ale trudno byłoby też nie zauważyć, że przyjęta przezeń argumentacja jest dość konsekwentną realizacją - zapowiedzianego na początku - dezyderatu opowiedzenia się po stronie ofiary niesprawiedliwego agresora. Krytycy tego poglądu starają się wobec tego zwrócić uwagę na rzeczywisty charakter sytuacji, w której się znalazł agresor z chwilą jego ujęcia. Nie jest on aktualnym, lecz potencjalnym agresorem ${ }^{31}$. Ponadto jeśli nawet przyjąć, że zdeterminowany pod wpływem okoliczności obrońca zmierza wprost do uśmiercenia agresora, to nie należy tu zapominać o warunkowym charakterze takiego sposobu jego działania we własnej obronie. O tym, że człowiekowi walczącemu o swoje życie nie zależy na śmierci agresora, świadczyłoby - według cytowanej autorki - zaniechanie samoobronny z chwilą osiągnięcia celu, tj. obrony życia ${ }^{32}$. Pogląd Slipki natomiast suponuje, że posunięcia obrońcy mogą być czasem w dużej mierze uwarunkowane, i w tym sensie na nim wymuszone, posunięciami podejmowanymi ze strony agresora. Znamienny jest przy tym fakt, że Ślipko także zaleca zaatakowanemu człowiekowi, by broniąc własnego życia, usiłował najpierw odwołać się np. do ucieczki, obezwładnienia, nieśmieciosprawczego zranienia agresora itp. ${ }^{33} \mathrm{Nie}$ należy chyba sądzić, że byłby on skłonny zaaprobować jako moralnie dozwolone dobicie agresora w sytuacji, kiedy obrońca osiągnął swój cel. Byłoby to przekro-

\footnotetext{
30 B. Chyrowicz, Zamiar i skutki. Filozoficzna analiza zasady podwójnego skutku, Lublin 1997, s. 229.

31 Por. tamże, s. 237; A. SzosteK, „Nie będziesz zabijał!” (Wj 20, 13), „Ethos” 2 (1989) 5, s. 145.

32 Por. tamże, s. 58.

33 Por. T. Ślıpкo, Kara śmierci z filozoficznego..., art. cyt., s. 128.
} 
czenie obrony koniecznej. Dyskusja oscyluje zatem wokół kwestii prawa do życia agresora pozbawionego możliwości szkodzenia innym osobom. Podczas trwania agresji prawo to jest $\mathrm{w}$ określonym zakresie ograniczone. Jednakże $\mathrm{z}$ chwilą, kiedy zostaje popełnione zabójstwo, Ślipko zdaje się opowiadać za trwałą utratą prawa do życia jego sprawcy ${ }^{34}$. Byłby to trzeci specyficzny element konstytuujący pogląd tego autora na karę śmierci.

Ów pogląd ma podstawę w przekonaniu Ślipki o tym, że wprawdzie agresor zachował własne życie, ale od chwili popełnienia zbrodni, od kiedy nie ustało prawo jego ofiary do samoobrony, życie agresora nie ma już moralnego charakteru, którym się cieszyło zanim popełnił on zabójstwo. Natomiast egzystencja ofiary, choć uległa niespodziewanemu przerwaniu, nadal go zachowuje. W oparciu o to Ślipko może powiedzieć, że kara śmierci nie godzi w moralną wartość życia agresora, a jedynie w jego strukturę ontyczną. Taki pogląd zdaje się być z kolei konsekwencją zastosowania jego ogólnej tezy głoszącej pewną odrębność ontycznego i moralnego aspektu życia ludzkiego. Nie sposób w takim razie uchylić się od pytania o generalną zasadę, na której opierałoby się utrata prawa do życia przez takiego agresora, który został ubezwłasnowolniony wskutek zastosowania wobec niego środków penitencjarnych. Czy polegałaby ona na tym, że nieuszanowanie jakiegoś dobra, chronionego określoną normą, niesie ze sobą wykluczenie winowajcy spod obowiązywalności tej normy? A jeśli tak, to czy jej uszczegółowieniem byłaby zasada, w myśl której świadome niedostosowanie się do normy „nie zabijaj” automatycznie powoduje wykluczenie zabójcy spod jej obowiązywalności w odniesieniu do niego? Niezależnie od tego, jakiej odpowiedzi udzieli się na te pytania, należy zachować w pamięci to, co Ślipko wyraźnie podkreśla. Mówi on o szczególnej roli przypadającej życiu, gdy chodzi o samospełnienie się człowieka, które jest procesem istoty osobowej. Na tej podstawie przypomina on i podkreśla szczególne miejsce, jakie w relacjach międzyosobowych ma i powinien mieć respekt zwłaszcza wobec cudzego życia. Wreszcie w świetle tego wszystkiego Ślipko broni też ograniczonej dopuszczalności sankcji kapitalnej. W całym systemie sprawiedliwości karnej jej obecność ma co prawda wyjątkowy charakter, ale jest ona konieczna, ponieważ wyjątkowo ohydne jest przestępstwo, które pod tę karę podpada. Wydaje się stąd, że Ślipko nie byłby skłonny, by ta nadzwyczajna okoliczność mogła uchodzić za wzorzec analogicznego postępowania gdzie indziej, tj. w odniesieniu do przypadków wykroczenia przeciwko innym dobrom niż życie. Reasumując: sposób usprawiedliwienia kary śmierci, który Ślipko proponuje, może sprawiać wrażenie, że nie wyklucza się w nim możliwości utraty prawa do życia. Interesująca więc byłaby odpowiedź na pytanie, czy kara śmierci powinna być konsekwentnie stosowana również w praktyce życia penalizacyjnego ${ }^{35}$.

\footnotetext{
34 Por. H. Niemiec, Moralne aspekty orzekania i stosowania kary śmierci, „Częstochowskie Studia Teologiczne" (2001) 29, s. 59.

35 Por. T. Ślıpкo, Kara śmierci z teologicznego..., dz. cyt., s. 167.
} 


\title{
RESIMÉ
}

Larticle présente le point de vue de Tadeusz Ślipko SJ sur la peine de motr, qui se qualifie de „rétentionniste” modéré. Dans la justification de cette peine, Ślipko se réfère à l'axiologie de la vie humaine subordonnée à la dignité de la personne. A ce titre, la vie humaine est inviolable mais dans une situation d'agression imminente, l'hommepersonne dispose d'un droit de légitime défense. La peine de mort, ne dépassant pas le carde de cette légitime défense, est une rétribution juste pour un homicide volontaire prémédité. Par la peine de mort, éliminant sans retour le meurtrier de la société est affirmé l'inviolabilité de la vie d'un être humain innocent

\section{Admissibility of Death Penalty formulated by Tadeusz Ślipko Death Penalty as a recapitulation of justified defence.}

\author{
SUMMARY
}

The above article presents a critical analysis of a conception of limited admissibility of death penalty by Tadeusz Ślipko (restrained retention).

Its essence is based on the fact that the victim of a wrongful aggressor has got the right to effectively defend his/her life. The source of such law lies in the absolute inviolability of innocent human's life as a fundamental right of every man. In case of efficient act of aggression (cold - blooded murder), the state takes over the right to effectively defend the victim's right of life by administering the perpetrator the death penalty ("life for life"). 